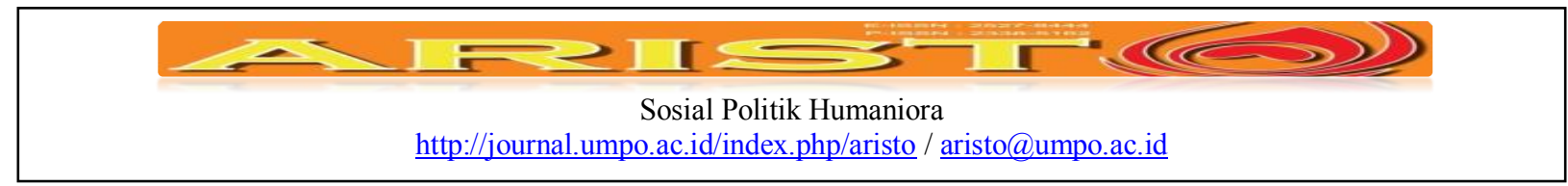

\title{
Strategi pembangunan pariwisata internasional berbasis pertanian organik
}

\author{
"shining batu" \\ Yusuf Adam Hilman \\ Prodi Ilmu Pemerintahan, FISIP \\ Universitas Muhammadiyah Yogyakarta \\ 545471adamongis@gmail.com / adamhilman@umpo.ac.id
}

\begin{abstract}
Natural potential and also local knowledge possessed by Batu, a great asset that can be implied to improve the welfare of the community, through the program "Shining Batu". This study aims to look at how the tourism development strategy undertaken by the City of Batu. This study used qualitative methods, with some data collection techniques, such as: interviews, documentation, Batu via Program "Shining Batu" want to change Batu become central areas of organic farming, based tourism International, therefore, the development program of the region, the perceived has a lot of benefits to the people of Batu. At the core strategies that do include several steps, namely: mapping the existing potential, then design and validate the rule of law as the foundation for the implementation of the program, which is the umbrella law, after which it then processes Sounding program through the activities - the activities and the media.

keywords: Regional Development, Innovation, Program Shining Batu, Tourism, Organic Farming.
\end{abstract}

\begin{abstract}
Abstrak
Potensi alam dan juga kearifan lokal yang dimiliki oleh Kota Batu, merupakan modal besar yang dapat di implikasikan untuk meningkatkan kesejahteraan masyarakat, melalui program "Shining Batu". Penelitian ini bertujuan untuk melihat bagaimanakah strategi pengembangan kepariwisataan yang dilakukan oleh Kota Batu. Penelitian ini menggunakan metode kualitatif, dengan beberapa teknik pengumpulan data, seperti: wawancara, dokumentasi, Kota Batu melalui Program "Shining Batu" ingin merubah Kota Batu menjadi daerah sentra pertanian organik, yang berbasis kepariwisataan Internasional, oleh karena itu program pengembangan wilayah tersebut, dirasakan telah banyak memberikan mafaat kepada masyarakat Kota Batu, Pada intinya strategi yang dilakukan meliputi beberapa langkah, yaitu: melakukan pemetaan terhadap potensi yang ada, kemudian merancang dan mengesahkan aturan hukum sebagai landasan untuk pelaksanaan program, yang menjadi payung hukum, setelah itu kemudian proses Sounding program melalui kegiatan - kegiatan dan juga media.

Kata Kunci: Pengembangan Wilayah, Inovasi, Program Shining Batu, Pariwisata, Pertanian Organik.
\end{abstract}

\begin{tabular}{|ll|}
\hline Submite & $: 10$ Nov 2016 \\
Review & $:$ 30 Nov 2016 \\
Accepted & $:$ 01 Jan 2017 \\
Surel Corespondensi & $:$ darwisnasution@gmail.com \\
\hline
\end{tabular}

Yusuf Adam Hilman / Strategi pembangunan pariwisata "shining batu" / 04/ Vol. 5. No. 1. Tahun 2017 


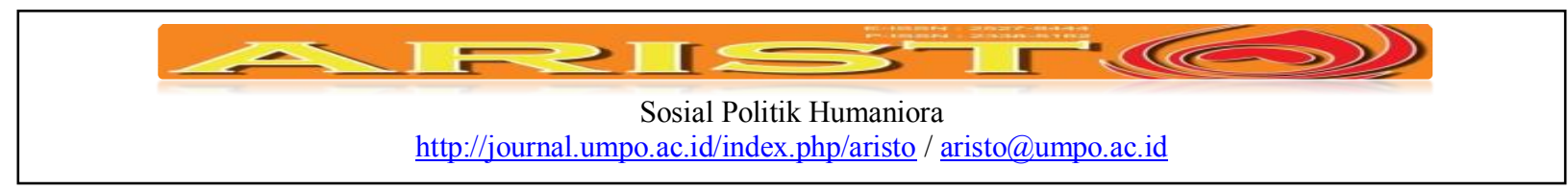

\section{Pendahuluan}

Kota Batu merupakan salah satu daerah yang berada di wilayah Malang raya, hasil pemekaran dari Kabupaten Malang bagian utara, kota ini memiliki panorama yang cantik, Indah, dengan cuaca yang dingin serta sejuk, selain itu Kota Batu juga di kenal sebagai kota penghasil Apel, yang menjadi produk unggulan di bidang pertanian. Hal tersebut karena ditopang oleh kondisi topografis yang sangat cocok untuk kegiatan di sektor pertanian. Keadaan topografi dan klimatologi Kota Batu memiliki dua karasteristik yang berbeda. Karakteristik pertama yaitu bagian sebelah utara dan barat yang merupakan daerah ketinggian yang bergelombang dan berbukit. Sedangkan karakteristik kedua, yaitu daerah timur dan selatan merupakan daerah yang relatif datar meskipun berada pada ketinggian 800 - 3000m dpl. Kota Batu dikelilingi Gunung Panderman, Gunung Banyak, Gunung Welirang, dan Gunung Bokong, Kondisi klimatografi Kota Batu antara lain memiliki suhu minimum $24-18^{\circ} \mathrm{C}$ dan suhu maksimum $32-28^{\circ} \mathrm{C}$ dengan kelembaban udara sekitar 75-98\% dan curah hujan rata-rata 875-3000 mm per tahun. Karena keadaan tersebut, Kota Batu sangat cocok untuk pengembangan berbagai komoditi tanaman sub tropis pada tanaman holtikultura dan ternak. (Nurhidayati, 2009)

Keunggulan kompetitif yang dimiliki oleh Kota Batu, di sektor pertanian, sangat ditunjang oleh faktor geografis dan topografi, sehingga alam menjadi bagian yang penting, dan tidak dapat dipisahkan dengan masyarakat yang ada di Kota Batu, dalam perjalanan waktu, pembangunan sektor pertanian yang ada di Kota Batu dirasa tidak tertangani dengan baik, dan juga kurang optimal, bahkan cenderung kurang diperhatikan, padahal mayoritas penduduk yang ada di Kota Batu, merupakan petani, baik yang menggarap lahannya sendiri maupun menggarap lahan orang lain. Permasalahan pembangunan sektor pertanian terlihat pada tataran kebijakan, terutama pada ranah implementatif, hasilnya bisa kita lihat jika kualitas pertanian yang ada di Kota Batu semakin hari - semakin menurun, salama ini kebijakan yang dilaksanakan, kurang maksimal karena kurang menyentuh pada lapisan masyarakat bawah, bentuk - bentuk penguatan sumberdaya manusia dan kondisi alam, contohnya: tidak adanya pelatihan bagi para petani terkait dengan bagaimana cara merawat, mengolah, serta memberdayakan pertanian yang berkualitas, akibatnya ekosistem tanah menjadi kurang baik dan hasil panen tidak sesuai dengan ekspektasi yang diharapkan. Hal ini jika dibiarkan saja, akan mengancam keberlangsungan pembangunan pertanian yang ada di Kota Batu. Persoalan yang juga menjadi problem 


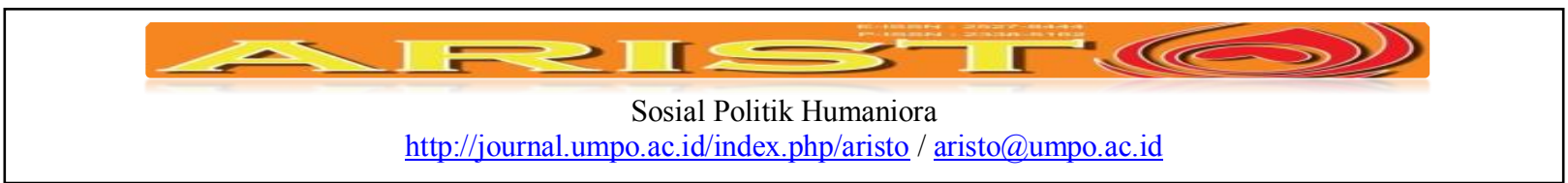

penghambat kemajuan pertanian di Kota Batu adalah pengalihan fungsi lahan pertanian, yang disebabkan karena perkembangan wilayah kemudian masyarakatnya secara perlahan - lahan mulai meninggalkan pertanian, dan menjual lahan mereka, karena memiliki harga jual yang tinggi. Hilangnya lahan pertanian karena perkembangan Kota Batu, membuat kerisauan berbagai kalangan, terutama steakholder, mengingat masyarakat kota Batu, sebagian besar mengandalkan mata pencaharian dari sektor pertanian, kondisi itu ternyata membuat Eddy Rumpoko sebagai Walikota Batu, untuk kembali menggeliatkan sektor pertanian, guna mewujudkan Kota Batu yang bersinar, dan berkemajuan.

Realitas pembangunan pertanian yang dilaksanakan di Kota Batu adalah upaya untuk mengarahkan pengembangan pertanian organik sebagai wujud pembangunan pertanian berkelanjutan hal tersebut tertuang sebagai kebijakan pembangunan bidang pertanian pada dokumen Rencana Strategis Dinas Pertanian dan Kehutanan Kota Batu Tahun 2007-2012, namun rencana aksi pertanian organik sebagai dokumen perencanaan yang menjadi pedoman teknis dan peta jalan dalam pelaksanaan pengembangan pertanian organik di Kota Batu sampai penelitian ini dilakukan belum ada. Adapun berbagai bentuk kegiatan yang terkait dengan upaya pengembangan pertanian organik di Kota Batu mulai gencar dilakukan sekitar tiga tahun terakhir. (Fadlina, Supriyono, \& Soeaidy, 2013)

Dengan kata lain pengkonversian lahan pertanian menjadi lahan non pertanian semakin cepat. Konversi lahan yang tidak terkendali disebabkan oleh pembangunan yang tidak merata serta kurangnya memperhatikan aspek lingkungan. Laju pertumbuhan dan pertambahan penduduk yang cukup tinggi sendiri merupakan determinan utama konversi lahan pertanian. Dan ada pula lain halnya dalam hal para wisatawan yang kebanyakan dari luar Kota Batu sendiri sangat tertarik untuk berinvestasi di Kota Batu ini karena udara yang sangat bagus dan masih asli, tidak seperti di perkotaan pada umumnya yang mana polusi cukup tinggi. Dengan adanya perubahan yang terjadi menjadikan Kota Batu sebagai lahan untuk berinvestasi untuk jangka panjangnya yaitu sebagai contohnya untuk pembuatan rumah tinggal yang baik tidak disewakan maupun disewakan, restoran, bahkan menjadi hotel baik dari tingkat hotel melati sampai hotel berbintang. (Putra, 2015)

Kompleksitas persoalan yang terjadi di wilayah Kota Batu, merupakan sebuah gambaran tentang bagaimana seharusnya wilayah ini dikembangkan, melalui potensi yang nantinya

Yusuf Adam Hilman / Strategi pembangunan pariwisata "shining batu" / 04/ Vol. 5. No. 1. Tahun 2017 


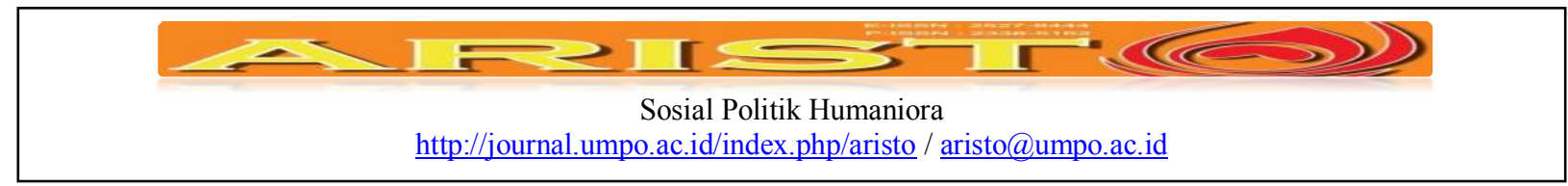

diharapkan bisa mengurai persoalan pertanian di Kota Batu, Gagasan - gagasan yang bermunculan untuk Kota Batu, kemudian mulai mencuat, salah satunya yaitu, terkait program “Shining Batu”, yang digagas oleh Walikota Eddy Rumpoko, program ini merupakan inisiatif walikota yang ingin menggagas pembangunan pertanian organik berbasis pariwisata internasional. Dengan asumsi dasar bahwa Kota Batu bisa mengembangkan dan juga memaksimalkan potensi yang di miliki untuk berbagai kegiatan ke Pariwisataan.

Kota Batu dibentuk sebagai daerah otonom baru, karena sebelumnya secara administratif menjadi bagian dari pemerintahan Kabupaten Malang. Pada tahun 2002 status kotatif Batu ditingkatkan menjadi pemerintah kota, kemudian Imam Kabul (2002 hingga 2007) dilantik sebagai walikota pertama Kota Batu yang mencanangkan visi "Batu Agropolitan Bernuansa Pariwisata dengan Masyarakat Madani”. Melanjutkan visi walikota sebelumnya, dibawah kepemimpinan Eddy Rumpoko selaku walikota Batu (periode 2007-2012 dan 2012- 2017) dengan mengusung visi misi yaitu "Mewujudkan Kota Wisata Batu sebagai Sentra Pertanian Organik Berbasis Kepariwisataan Internasional”. (Atantia Riski Ananda, 2007)

Sektor pariwisata mampu menyumbang peningkatan pertumbuhan dan pendapatan daerah Kota Batu, sedangkan kegiatan pertanian yang menopang kehidupan hampir sebagian besar penduduk kota Batu memberikan sumbangan yang tidak terlalu besar. Sektor pertanian merupakan sektor yang unik dan mempunyai ciri khas yang tersendiri dalam sektor perekonomian. Sektor ini sangat banyak menampung luapan tenaga kerja, tetapi secara umum kontribusi sektor pertanian dalam menyusun Produk Domestik Regional Bruto (PDRB) tidaklah sebesar sektor perdagangan hotel dan restoran. Pada tahun 2000 sektor pertanian menyumbang nilai PDRB sebesar 22,36 \% dan di tahun 2010 turun menjadi 20,64 \% sedangkan sektor tersier (perdagangan, hotel dan restoran, jasa, angkutan, komunikasi) sebesar 65, $95 \%$ di tahun 2000 dan 68,67 \% di tahun 2010 (BPS Kota Batu, 2011).

Konsep pengembangan wilayah Kota Batu sebagai sentra pertanian organik berbasis pariwisata Internasional, yang tertuang dalam program "Shining Batu", kemudian banyak merubah wajah Kota Batu, menjadi salah satu Wilayah yang berhasil mengembangkan Potensi dengan kegiatan pariwisatanya. 


hosial Politik Humaniora
http://journal.umpo.ac.id/index.php/aristo / aristo@umpo.ac.id

\section{Tabel 1}

Jumlah Kunjungan Wistaawan Mancanegara ke Kota Batu

\begin{tabular}{ccccc} 
Tahun & 2011 & 2012 & 2013 & 2014 \\
Total & 10318 & 11301 & 11409 & 12422 \\
\multicolumn{5}{c}{ Keperluan } \\
Liburan & 9702 & 10782 & 10738 & 11631 \\
Bisnis & 394 & 401 & 425 & 449 \\
Konvensi & 197 & 87 & 209 & 287 \\
Penelitian & 25 & 31 & 37 & 55
\end{tabular}

Sumber : Dinas Pariwisata Kota Batu.(Intyaswono, 2016)

Data tersebut, memberikan gambaran bahwa perjalanan kota Batu untuk menjadi salah satu gerbang pariwisata internasional di Indonesia, memerlukan waktu dan proses panjang, dalam melakukan konsep dan implementasi desain pembangunan kewilayahan yang berbasis kearifan lokal. Konsep pengembangan pertanian yang dipadukan dengan sistem kepariwisataan, tentunya sangat menarik untuk dikaji, karena Kota Batu oleh khalayak dianggap telah berhasil mengembangkan konsep pertanian organik berbasis pariwisata internasional melalui Program "Shining Batu”, oleh karena itu, bagaimanakah strategi pengembangan wilayah tersebut, harus menitik beratkan pada strategi dan proses implemntasi yang partisipatif dengan melibatkan masyarakat, pemerintah dan juga pihak swasta, supaya kebijakan tersebut lebih efektif dan sesuai dnegan harapan.

Beberapa kajian yang relevan juga menegaskan hal sama, bagaimana pentingnya pengembangan daerah wisata yang berkesinambungan, seperti uraian yang ada di bawah ini. Hasil dari penelitian kemudian dijadikan sebagai masukan untuk pengembangan dan pengelolaan kawasan wisata di Desa Bedono yaitu sebuah strategi pengembangan dan pengelolaan desa wisata Bedono yang berasal dari potensi masalah yang ada di desa Bedono dan didukung oleh kebijakan serta organisasi yang ada.(Suwandono, 2015)

Berdasarkan hasil kajian yang sudah dipaparkan, maka terdapat beberapa kesimpulan yang dapat ditarik, yakni: a. Implementasi Kebijakan Pariwisata di Kabupaten Manggarai Barat lebih cenderung menggunakan pendekatan top-down. a). Akibatnya ruang partisipasi bagi masyarakat sangat terbatas. b). Jejaring dalam mempromosikan Pariwisata Berbasis Kearifan Lokal di Kabupaten Manggarai Barat sangat terbatas. c). Kinerja implementator/agensi kebijakan belum optimal. d). Terbatasnya kuantitas dan kualitas sumber daya manusia yang tersedia. e). 


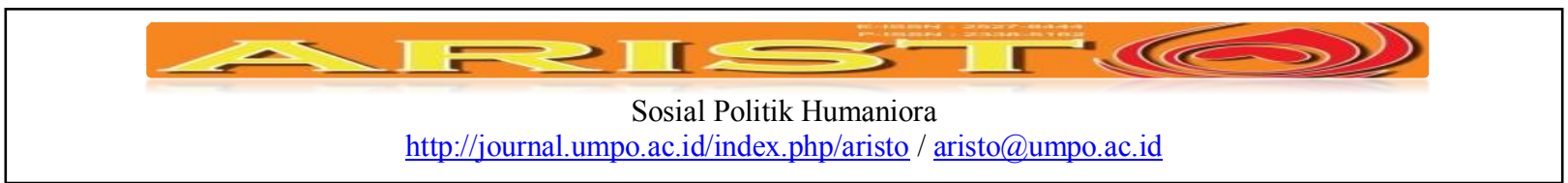

Ego sektoral yang masih sangat kuat, sehingga koordinasi dan komunikasi tidak berjalan efektif. f). Lingkungan Sosial, Ekonomi, dan Politik yang membungkus sirkulasi kehidupan masyarakat di Kabupaten Manggarai Barat cenderung menghalangi terjadinya Implementasi Kebijakan efektif.(Jupir, 2013)

\section{METODE PENELITIAN}

Metode yang dilakukan dalam penelitian ini adalah deskriptif kualitatif, dengan teknik pengumpulan data berupa: wawancara, dan juga dokumentasi, serta menggunakan analisis kritis, untuk melihat serta mendeskripsikan konsep "Shining Batu", yang sudah dilakukan oleh Pemerintahan Kota Batu.

W. Lawrence Neuman mencoba mengidentifikasi 4 faktor yang terkait dengan orientasi dalam penelitian yang menggunakan metode kualitatif. Orientasi pertama terkait dengan pendekatan yang digunakan terhadap data. Metode kualitatif memperlakukan data sebagai sesuatu yang bermakna secara intrinsik. Dengan demikian, data yang ada dalam penelitian kualitatif bersifat "lunak", tidak sempurna, imaterial, kadangkala kabur dan seorang peneliti kualitatif tidak akan pernah mampu mengungkapkan semuanya secara sempurna. Namun demikian, data yang ada dalam penelitian kualitatif bersifat empiris, terdiri dari dokumentasi ragam peristiwa, rekaman setiap ucapan, kata dan gestures dari objek kajian, tingkah laku yang spesifik, dokumen-dokumen tertulis, serta berbagai imaji visual yang ada dalam sebuah fenomena sosial (Neuman, 1997: 328).(Somantri, 2005)

\section{HASIL DAN PEMBAHASAN}

\section{HASIL}

\section{Potensi Wisata Kota Batu}

Wisata Alam Cangar - Lokasi: Berada di Dusun Cangar, Desa Sumber Brantas (Masuk Kawasan Tahura R. Suryo) - Daya tarik: Sumber air panas dan dipercaya bahwa air panas cangar dengan kandungan belerangnya, dapat menyembuhkan penyakit kulit dan rematik. Bumi perkemahan Flora dan fauna yang masih alami. Kawasan ini merupakan taman wisata yang berada di Taman Hutan Raya (Tahura) R. Suryo. Terdapat taman, tempat bermain dll. Fasilitas yang ada: tempat parkir, MCK dan PKL. 


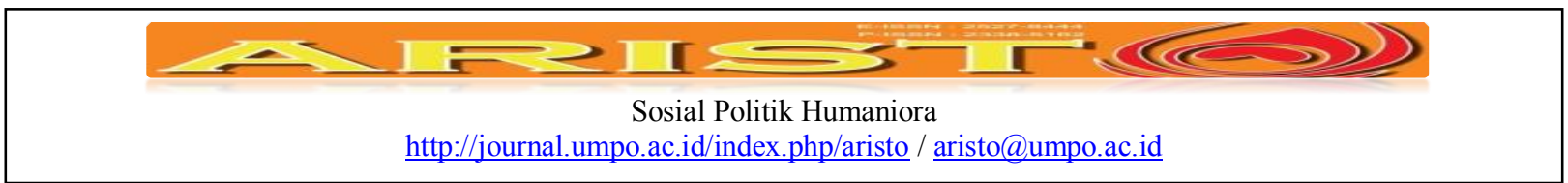

Wisata Alam Air Terjun Cuban Talun - Lokasi: Di Dusun Junggo, Desa Tulungrejo Kecamatan Bumiaji - Daya Tarik: Menikmati pemandangan alam dan keindahan air terjun, ketinggian Air Terjun sekitar 75 meter. Terdapat area perkemahan. Terdapat goa peninggalan Jepang pada tahun 1941. Daya tarik lainnya adalah Area Camping Ground dan taman bermain sebelum mema- suki area air terjun. Tersedia fasilitas penunjang antara lain: tempat parkir, kios dan warung, sarana ibadah, ka- mar mandi/wc umum dan pos jaga.

Wisata Alam Air Terjun Cuban Rais Lokasi: Di Desa Tlekung, Kecamatan Junrejo, untuk menuju lokasi melalui jalan setapak sekitar $2 \mathrm{Km}$. Daya Tarik: Pemandangan alam sangat indah alami sambil menikmati keindahan air terjun, ketinggian Air Terjun sekitar 15 meter.

Wisata Alam Gunung Panderman - Lokasi: Lokasi Di Desa Oro-Oro Ombo Kecamatan Batu, Daya tarik: Pemandangan alam Petu- alangan dan pendakian Kawasan hutan Melihat Sunrise Kebaradaan flora dan fauna.

Kawasan Wisata Songgoriti - Lokasi: Lokasi Di Kel. Songgokerto Kecamatan Batu Daya Tarik: Potensi alam terutama pada pemandangan alam, wisata rekreasi keluarga dan wisata budaya Candi Songgoriti atau Candi Supo. Daya tarik lain yaitu Payung yang merupakan wisata koridor dengan kegiatan PKL yang sudah terorganisir. Didukung dengan fasilitas seperti kolam renang (Tirta Nirwana), sepeda air, taman bermain, area pancing, restoran dan warung. Terdapat hotel, villa atau rumah peristirahatan disekitarnya.

Wisata Selecta - Lokasi: di Desa Tulungrejo Kecamatan Bumiaji - Daya tarik: Potensi alam yang dikemas secara baik menjadi wisata keluarga. Terdapat pasar wisata, sejarah Bung Karno dan pemandangan alam yang cukup menarik. Fasilitas wisata, seperti: kolam renang, pasar buah (terutama apel dan sayuran) taman dan pemandangan alam pegunungan yang indah. Telah dilengkapi dengan lahan parkir yang luas, kios souvenir dan makanan, serta pasar bunga.

Wisata Jatim Park - Lokasi: Lokasi Di Kel. Temas Kecamatan Batu. Daya Tarik: Jawa Timur park adalah tempat wisata buatan yang dulu merupakan lahan tempat budidaya apel. Fasilitas penunjangnya meliputi taman bermain, kolam pemandian, serta pusat-pusat perbelanjaan. Keg- iatan wisata keluarga dan ilmu pengetahuan bagi anak.

Batu Night Spectacular (BNS) - Lokasi: Lokasi Di Desa Oro-Oro Ombo Kecamatan Batu, Daya Tarik: Aneka wahana permaian, seperti: gallery hantu, slalom tes, sepeda udara, lam- 


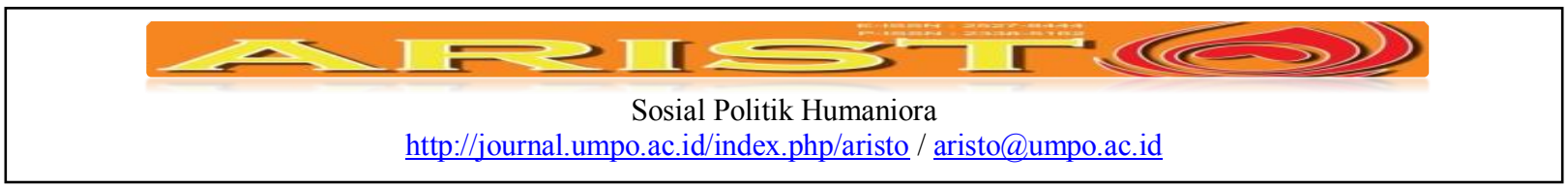

pion garden, trampoline, drag race, mouse coaster dan lainnya. Fasilitas penunjangnya meliputi tempat parkir, food court, night market.

Museum Satwa - Lokasi Di Desa Oro-Oro Ombo Kecamatan Batu - Daya Tarik: Berbagai macam replika satwa dunia. Fasilitas penunjangnya meliputi hotel, tempat parkir, food court.

Paralayang Gunung Banyak - Lokasi: Berada di Desa Gunungsari (Berdekatan Dengan Wilayah Perbatasan Dengan Kab. Malang). Daya tarik: Pemandangan alam yang dapat melihat Kota Batu dari atas Olahraga paralayang hingga skala internasional Di kawasan wisata Gunung Banyak telah tersedia klub yang akan memandu kegiatan olah raga ini. Fasilitas: gardu pandang, warung, MCK, dan tempat singgah

Downhill - Lokasi: Berada di Gunung Klemuk, Dusun Songgoriti, Desa Songgokrto Kecamatan Batu - Daya tarik: Even rutin dilaksanakan setiap tahun hingga skala nasional Panjang lintasan sekitar 1,2 Km

Arung Jeram (Rafting) - Lokasi: Berada di Desa Torongrejo, Kecamatan Junrejo - Daya tarik: Keindahan alam sepanjang jalur rafting Rafting menyusuri arus Sungai Brantas. Hash Kota Wisata Batu juga memperkenalkan wisata jalan sehat hash dengan rute mengelilingi area perbukitan sambil menikmati pemandangan alam. Rutehash sepanjang kurang lebih $8 \mathrm{~km}$. Even ini dilaksanakan secara rutin setiap tahun. Peserta even selain Malang Raya juga diikuti oleh tingkat regional.

Agro Kusuma - Lokasi: di Desa Punten, Desa Sidomulyo dan Desa Bumiaji Kecamatan Bumiaji, Daya Tarik: Wisata petik apel, petik jeruk petik sayur mayur. Wisatawan juga akan mendapatkan pengetahuan tentang tata cara budidaya tanaman, perawatan dll. Nuansa pedesaan yang didukung dengan keindahan alam. Agro Bunga Sidomulyo - Lokasi: di Desa Sidomulyo dan Sekitarnya, Daya Tarik: Merupakan desa binaan dari Dinas pariwisata dan Dinas Pertanian dalam pengembangan dan pembudidayaan tanaman bunga. Merupakan sentra penghasil bunga yang dapat dijadikan daya tarik wisata khususnya bagi para wisatawan yang berkunjung ke Kota Batu. Terdapat Pasar Bunga serta fasilitas pendukung lainnya.

Wisata Kerajinan: Jenis Kerajinan: Kerajinan batik di Desa Sisir Kecamatan Batu, Desa Pandanrejo Kecamatan Bumiaji Keraji- nan cobek dan alat rumah tangga di Desa Junrejo Kecamatan Junrejo Kerajinan batu onix dan keramik di Desa Dadaprejo Kecamatan Junrejo 


\begin{tabular}{|c|cccc} 
Sosial Politik Humaniora \\
http://journal.umpo.ac.id/index.php/aristo / aristo@umpo.ac.id
\end{tabular}

Kerajinan gong di Desa Junrejo Kecamatan Junrejo Kerajinan gerabah di Desa Dadaprejo dan Desa Junrejo Kecamatan Junrejo Kerajinan anyam-anyaman di Desa Junrejo Kecamatan Junrejo.

Desa Wisata Bukit Apel - Bumiaji Kebun Apel Bumiaji: Wisata Petik Apel Wisata Pendidikan (Melihat KegIatan Petani Apel: Proses Tanam, Perawatan dll) yang Diampingi Guide Masyarakat Setempat. Pemandangan Alam Pegunungan dan Hamparan Kebun Apel.

Pertunjukan Kesenian Daerah Desa Bumiaji Yaitu Senterewe (Tarian Kuda Lumping).

Padang Rumput Oro - Oro: Terletak Di Dataran Tinggi Merupakan Daya Tarik Bagi Wisatawan untuk menikmati keindahan pemandangan Alam Desa Bumiaji Maupun Hamparan Wilayah Kota Batu. Wisatawan Juga dapat Melakukan Kegiatan Olah Raga, Menikmati Pemandangan Alam, Bersantai dll.

Wisata Budaya, Atraksi Budaya dan Kesenian: Grebek Suro Selamatan Desa Kesenian Bantengan, Ludruk, Reog, Campusari, Karawitan, Pencak Silat, tayub, kuda lumping dan lain sebagainya. Festival bunga, karnaval dan mobil hias Potensi: Mempertahankan dan melestarikan budaya masyarakat Sebagai salah satu aset pendukung pariwisata Kota Batu.

Wisata Kuliner - Kondisi: BTC PKL di Kawasan Payung Rumah makan, restoran, kafe, Potensi: Sebagai salah satu wisata pendukung (wisata kuliner) yang mempunyai ciri khas Masih perlu dikembangkan lebih lanjut melalui investasi.

Alun - Alun Kota Batu - Atraksi: Bianglala Air Mancur Air Menari Playground Bangunan Apel, Strawbery, Wortel Taman dst. Potensi: Tempat Rekreasi Tempat Bersosialisasi dan Bersantai.(Angka, 2013)

Potensi tersebut, merupakan keunggulan yang dimiliki oleh Kota Batu dan bisa dijadikan sebagai obyek yang bisa digali dan dikembangkan dalam rangka menopang program "Shining Batu" 


Sosial Politik Humaniora
http://journal.umpo.ac.id/index.php/aristo / aristo@umpo.ac.id

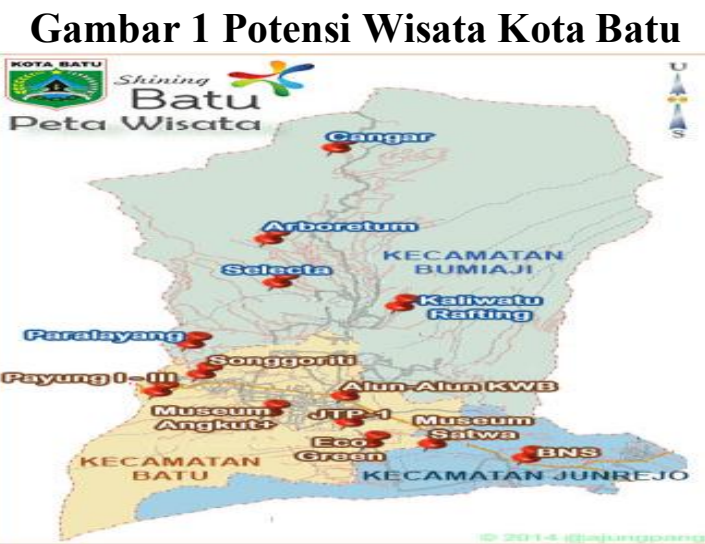

Sumber diolah dari: $\underline{\text { www.batukota.go.id }}$

\section{Landasan Yuridis Kebijakan Pengembangan Pertanian Organik dan Pariwisata Internasional, melalui program "Shining Batu"}

1. Undang-undang Nomor 32 Tahun 2004 tentang Pemerintahan Daerah, juncto Peraturan Pemerintah Nomor 38 Tahun 2007 tentang Pembagian Urusan Pemerintahan antara Pemerintah, Pemerintahan Daerah Provinsi, dan Pemerintahan Daerah Kabupaten/Kota menyatakan bahwa sub Bidang Kebijakan Bidang Kepariwisataan adalah Pemberian Izin Usaha Pariwisata Skala Kota.

2. Undang - Undang Republik Indonesia Nomor 10 Tahun 2009 Tentang Kepariwisataan.

3. Peraturan Presiden Republik Indonesia Nomor 63 Tahun 2014 Tentang Pengawasan Dan Pengendalian Kepariwisataan.

4. Peraturan Pemerintah Nomor 38 Tahun 2007 tentang Pembagian Urusan Pemerintahan Antara Pemerintah, Pemerintahan Daerah Provinsi, dan Pemerintahan Daerah Kabupaten / Kota (Lembaran Negara Republik Indonesia Tahun 2007 Nomor 82, Tambahan Lembaran Negara Republik Indonesia Nomor).

5. Peraturan Daerah Kota Batu No. 1 Tahun 2013 tentang penyelenggaraan Kepariwisataan.

Visi Kota Batu Tahun 2012-2017:

"Kota Batu Sentra Pertanian Organik Berbasis Kepariwisataan Internasional" Ditunjang Oleh Pendidikan Yang Tepat guna Dan Berdaya Saing. Ditopang Oleh Sumberdaya 


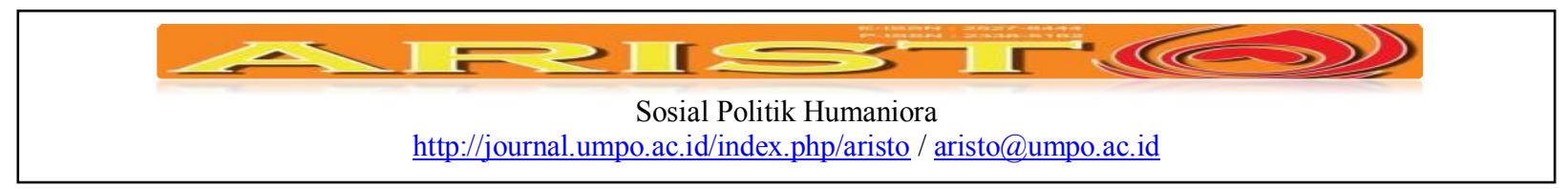

(Alam, Manusia,Dan Budaya) Yang Tangguh Diselenggarakan Oleh Pemerintahan Yang Baik,

Kreatif, Inovatif, Dijiwai Oleh Keimanan Dan Ketakwaan Kepada Tuhan Yang Maha Esa

\section{Misi Kota Batu}

1. Peningkatan Kualitas Hidup Antar Umat Beragama;

2. Reformasi Birokrasi Dan Tata Kelola Pemerintahan;

3. Mengembangkan Pertanian Organic Dan Perdagangan Hasil Pertanian Organik.

4. Meningkatkan Posisi Peran Serta Dari Kota Sentra Pariwisata Menjadi Kota Kepariwisataan Internasional.

5. Optimalisasi Investasi Daerah.

6. Peningkatan Kualitas Pendidik Dan Lembaga Pendidikan.

7. Peningkatan Kualitas Pelayanan Kesehatan.

8. Pengembangan Infrastruktur (Sektor Fisik) Khususnya Perkantoran Pemerintah, Fasilitas Publik, Prasarana Dan Sarana Lalu Lintas.

9. Meningkatkan Penyelenggaraan Pemerintah Desa, Guna Peningkatan Pelayanan Kepada Masyarakat;

10. Menciptakan Stabilitas Dan Kehidupan Politik Di Kota Batu Yang Harmonis Dan Demokratis.

11. Pemberdayaan Masyarakat Melalui Koperasi Dan UKM. (Visi \& Misi Pemerintah Kota Batu diakses dari http://shining-batu.com/visi-misi-kota-wisata-batu pada 20 Agustus 2016)

Secara hukum, Landasan Program Pengembangan Kepariwisataan di Kota Batu, memiliki landasan yang kuat, karena secara hirarkis dari tingkat Pusat, Daerah hingga Kabupaten / kota terdapat aturan yang secara sah mengatur, sehingga jelas, dalam pelaksanaanya. Selain itu dalam visi dan misi Kota Batu, secara tertulis disebutkan bahwa Kota Batu memiliki Visi untuk menjadikan Kota Batu Sebagai sentra pertanian organik yang berbasis wisata Internasional. Hal inilah yang akan dijadikan sebagai acuan pembangunan pariwisata yang bertajuk , "Shining Batu” 


http://journal.umpo.ac.id/index.php/aristo / aristo@,umpo.ac.id
Sosial Politik Humaniora

\section{"Shining Batu"}

Pemerintah mengembangkan program Shining Batu sebagai sarana untuk mengkomunikasikan dan mencerminkan keunggulan Kota Batu. Shining Batu dikomunikasikan melalui berbagai bentuk promosi yang memanfaatkan berbagai macam sarana komunikasi; menawarkan berbagai Paket Wisata; dan menyelenggarakan berbagai event rutin maupun yang bersifat insidentil. Sebagian besar responden yang mengunjungi Kota Batu bertujuan untuk berwisata, dimana jenis tempat wisata rekreasi menjadi pilihan utama dibanding tempat wisata alam. Hotel menjadi tempat utama bagi pengunjung yang menginap dan sebagian besar pengunjung melakukan kunjungan ke Kota Batu lebih dari sekali dalam satu tahun.(Miladiyah, 2014)

Menurut Sinal abidin (humas Pemkot Batu) jadi "Shining Batu" itu anu mas,,,,,$e h m m m . . .$. merupakan sebuah program pariwisata yg memadukan konsep pariwisata moderen dg konsep pertanian yg ramah lingkungan,,,,,,,praktek'e iku melalui kegiatan - kegiatan yg melibatkan masyarakat,,,,cek ne iso menciptakan Kota Batu yg cerah dan bersinar,,,,sesuai karo logone. (Shining Batu adalah program pariwisata yg memadukan konsep pariwisata moderen dg menekankan pada model pertanian yg ramah lingkungan organic, sebagai potensi lokal yang harus dikembangkan) (Hasil wawancara tanggal 20 Oktober 2016)

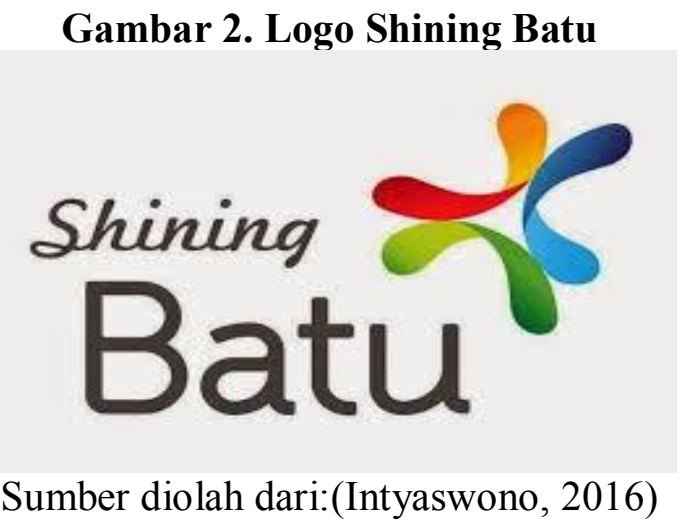

Secara rinci dijelaskan bahwa tiga: curve / garis lengkung yang membentuk logo merupakan representasi dari: 
a. Hijau $=$ pertanian

b. Merah-orange $=$ pariwisata

c. Biru $=$ pendidikan

Dengan filosofis dari brand tersebut, Kota Batu diharapkan lebih bersinar, baik dalam bidang pariwisata, pertanian dan pendidikan.(Intyaswono, 2016)

\section{Peran antar Lembaga dan Pemangku Kebijakan.}

Hasil dari penelitian ini menunjukkan bahwa dengan potensi dan keunggulan di sektor pertanian, pariwisata, dan pendidikan, Kota Batu dapat memiliki identitas yang kuat sebagai kota wisata. Implementasi City Branding Kota Batu selama ini telah dilakukan dan memenuhi 3 sektor utama yaitu pertanian, pariwisata dan pendidikan. City Branding ini bukan hanya sebagai alat promosi saja. Namun juga sebagai pemersatu dan pengikat dari seluruh pihak-pihak yang berurusan dengan pariwisata Batu agar semakin meningkatkan kualitas jasa atau produknya dalam menarik wisatawan mancanegara untuk dapat mengunjungi Kota Batu.(Intyaswono, 2016) Dalam rangka mendukung keberhasilan di bidang kepariwisataan dibutuhkan kerjasama usaha semua pihak. Peran serta semua pihak yang terkait baik itu masyarakat luas, swasta maupun pemerintah sangat dibutuhkan demi suksesnya pembangunan kepariwisataan. Kebijakan daerah yang dirumuskan dalam peraturan daerah dan peraturan kepala daerah. Oleh karena itu, pada prinsipnya peraturan daerah merupakan instrumen hukum yang secara yuridis formal diberikan kepada pemerintah daerah dalam menyelenggarakan pemerintahan di daerah. Dengan demikian, penataan perizinan usaha pariwisata daerah berakibat hukum bagi pemerintah daerah dapat menyelenggarakan perizinan usaha pariwisata sebagai upaya yuridis preventif sebagai instrumen administrasi dalam usaha pariwisata dalam peningkatan Pendapatan Asli Daerah. (Yeni Rosita. 2016)

Kesinambungan antar lembaga dalam memaksimalkan program "Shining Batu”, bisa dilihat dari bagaimana pola komunikasi, serta bentuk kerjasama yang intensif, sehingga membuahkan kegiatan - kegiatan atrau pun program - program yang berkesinambungan sehingga efek ganda dapat dirasakan oleh semua pihak. 


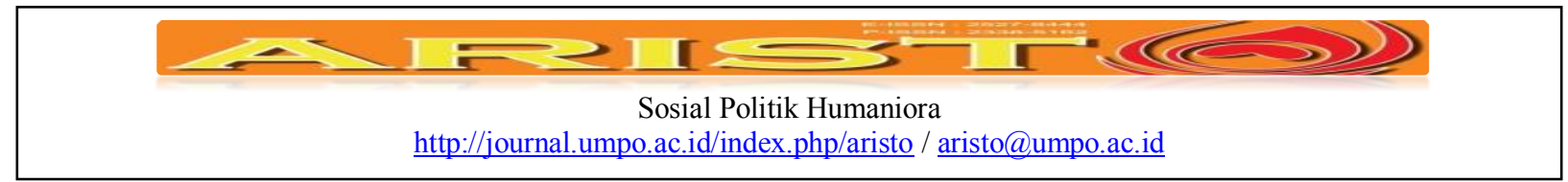

\section{Implementasi "Shining Batu"}

\section{Media Publikasi Shining Batu}

Menurut Kepala Humas pemerintah Kota Batu, menyatakan bahwa media yang digunakan oleh Humas pemerintah Batu dalam mempublikasikan program "Shining Batu”, diantaranya sebagai berikut: Media - media yang dipakai karo humas antare media cetak maupun elektronik, koyok: televisi lokal (agropolitan tv, malang tv dan lain - lain), televisi nasional (Kompas tv dan juga kompas tv) bahkan untuk pertengahan tahun ini kami telah melibatkan televisi prabayar asal singapura yaitu TLC dan ILC dan TLC yang khusus menyiarkan tayangan tentang destinasi wisata dan dapat diakses oleh 34 negara di sekitar 4 benua. (Hasil wawancara dengan kepala Humas Pemerintah Kota Batu Rabu 15 April 2016)

Beberapa publikasi terkait dengan promosi wisata "Shining Batu" bisa dilihat di media Youtube, bisa di buka di alamat url sebagai berikut: https://www.youtube.com/watch?v=2UBR5vLZ82A

\section{Event Shining Batu}

Konsep Shining Batu yang digagas oleh Pemerintah Kota Batu, kemudian dibuat aturan untuk menjadi payung hokum, barulah dibentuk program - program yang di soundingkan, kepada khalayak. Program - program tersebut kemudian di kemas melalui even - even wisata, yang diselenggarakan secara periodik, untuk memperkuat sounding "Shining Batu", kepada khalayak, dan pengungjung yang dating ke Kota Batu.

Gambar 3. Agenda Shining Batu

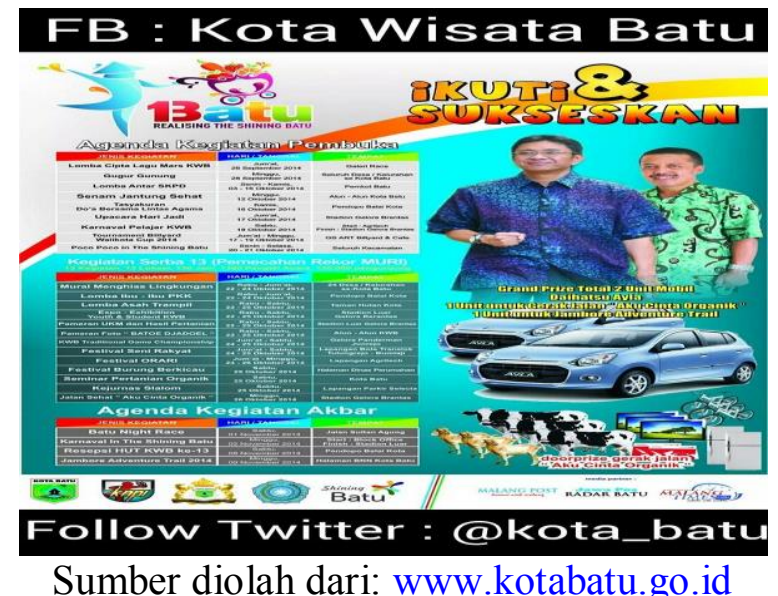

Yusuf Adam Hilman / Strategi pembangunan pariwisata "shining batu" / 04/ Vol. 5. No. 1. Tahun 2017 


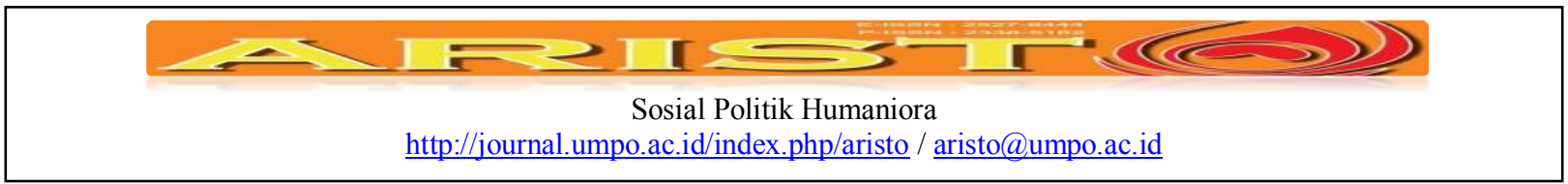

\section{Pembahasan}

Strategi pariwisata yang dilakukan oleh pemerintah Kota Batu, secara ringkas dapat dijelaskan melalui beberapa tahapan, yaitu: 1). Pemetaan potensi alam yang dimiliki, 2). Pembuatan Program Pariwisata yang selaras dengan Potensi alam khususnya dalam menggagas pertanian Organik, melalui Program "Shining Batu”, 3). Pembuatan landasan hukum, untuk pelaksanaan program, 4). Melakukan berbagai bentuk kerjasama antar lembaga untuk memudahkan, implementasi program, 5).Pembuatan berbagai publikasi dan even / kegiatan untuk mensiarkan program tersebut. Selain itu yang penting adalah bagaimana pengembangan pariwisata itu melibatkan masyarakat, sebagai bentuk partisipasi secara aktif, dalam mengembangkan daerah, sehingga ada sinergitas antara pemerintah, masyarakat dan pihak swasta.

Menurut Suansri (2003: 14) "CBT adalah pariwisata yang menitikberatkan keberlanjutan lingkungan, sosial, dan budaya kedalam satu kemasan. Hal ini dikelola dan dimiliki oleh masyarakat, untuk masyarakat, dengan tujuan memungkinkan pengunjung untuk meningkatkan kesadaran mereka dan belajar tentang masyarakat dan lokal cara hidup".(Suwandono, 2015) Implementasi Kebijakan Pariwisata Berbasis Kearifan Lokal di Kabupaten Manggarai Barat ditilik dari beberapa segi, yaitu partisipasi masyarakat (Pengembang, Pelestarian dan Pelaksanaan) Kearifan Lokal, Struktur Kelembagaan Dinas Kebudayaan dan Pariwisata Kabupaten Manggarai Barat, Pengalokasian Sumber daya (aktor, finansial, organisasi, fasilitas), komunikasi dan koordinasi; kondisi sosial, ekonomi dan politik, serta kepentingan dari stakeholder.(Jupir, 2013)

This research was to describe the government implementation of economic tourism policy and its impact on community through empowerment program in Batu City. As one of new autonomus region in east java, Batu City use geographic advantages that is concern in tourism sector to raise region economic development. Using qualitative fenomenology approach to analize. There are two strategic policy in Batu City that implementing in tourism development, first is conventional paradigm policy and then sustainable paradigm policy. Each implementation of the policy has brought different consequences and impact on development in Batu City. As a result, emerging programs aimed at improving the development of tourism to reduce conflicts that can occur and to increase community participation as empowerment through community

Yusuf Adam Hilman / Strategi pembangunan pariwisata "shining batu" / 04/ Vol. 5. No. 1. Tahun 2017 


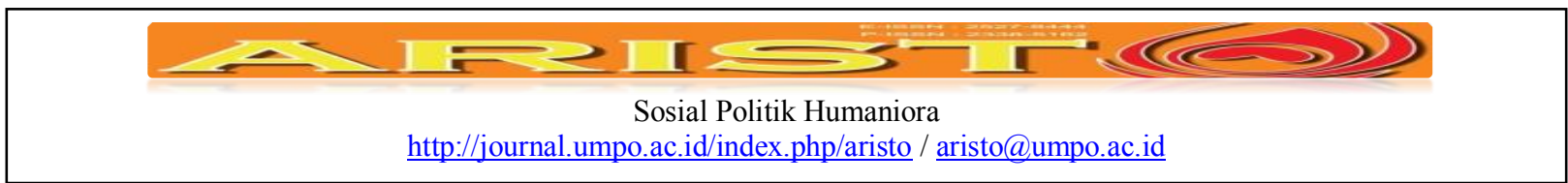

based tourism concept, increasing the role of local SMEs and creating city branding called

"Shining Batu". Success in community development in the area of tourism is determined from the role of stakeholders, and therefore required a synergy mindset and active participation of all entity to realize the welfare of society in Batu City.(Priambodo, 2015)

Menurut Inol Ertadiyansyah, S.H, MM. (Ka.Su.Bag.Publikasi \& Kerjasama Pers Pem.Kot. Batu) Lek prosedurnya,,,, Prosesnya itu Kepala bagian menmberikan instruksi dan berkomunikasi dengan kepala sub bagian peliputan dan kerjasama pers, tentang publikasi "Shining Batu", lalu sub bag peliputan atau bidang kami,,,, melanjutkan dg mencari berbagai macam data trus diolah mas, habis itu disusun dalam bentuk release yg akhire, ngasilno pers release, advertorial, karo videotron kemudian hasil iku dipublikasikan lewat media - media komunikasi. (pihak humas melakukan peliputan kemudian membuat release, yang kemudian menghasilkan publikasi di berbagai media, cetak, maupun elektronik). (Hasil wawancara tanggal 20 Oktober 2016)

Pengembangan pariwisata yang ada di Kota Batu, selain ebrsifat partisipatif, dengan melibatkan masyarakat, birokrasi dan pihak swasta, strategi khusus berupa publikasi merupakan hal penting, yang menjadi bagian khusus untuk membantu mensiarkan potensi wisata di Kota Batu, sehingga bisa sukses dan berhasil dengan gagasan Pariwisata Internasional berbasis pertanian organik.

\section{KESIMPULAN}

Terkait dengan pembangunan Pariwisata yang inovatif, pemerintah Kota Batu, menggagas program "Shining Batu” sebagai masterplan pariwisata Kota Batu, yang bertujuan untuk menjadikan "Kota Batu Sebagai sentra Pertanian Organik Berbasis Kepariwisataan Internasional" Secara umum gagasan ini ingin memadukan antara kekuatan Pertanian Organik dengan program pariwisata Internasional, sebagai primadona sumber pendapatan yang ada di Kota Batu. Strategi program "Shining Batu”, yaitu dnegan cara memetakan potensi wisata, kemudian membuat sebuah payung hukum, untuk mengatur kebijakan terkait pengembangan pertanian organik yang berbasis wisata Internasional, kemudian setelah itu membuat event event untuk mensiarkan program tersebut dengan menggunakan berbagai media. 


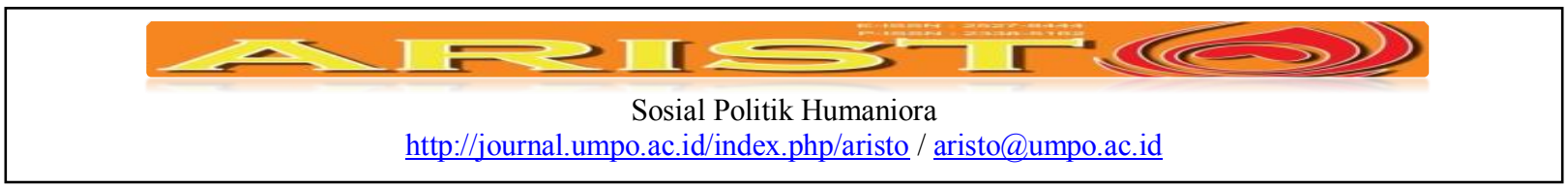

Strategi tersebut, dirasakan cukup berhasil dimana dalam perjalananya, kota Batu menjadi salahs atu garda terdepan di Indonesia dalam pengembangan ke Pariwisataan, hal itu juga bisa dilihat dari kunjungan wisatawan ke Kota Batu. Program - program yang dijalankan oleh Kota Batu, terkait "Shining Batu” perlu ditingkatkan lagi, termasuk arah kebijakan di bidang pertanian organic, karena di Kota Batu masih banyak penggarapan lahan yang tidak ramah lingkungan. 


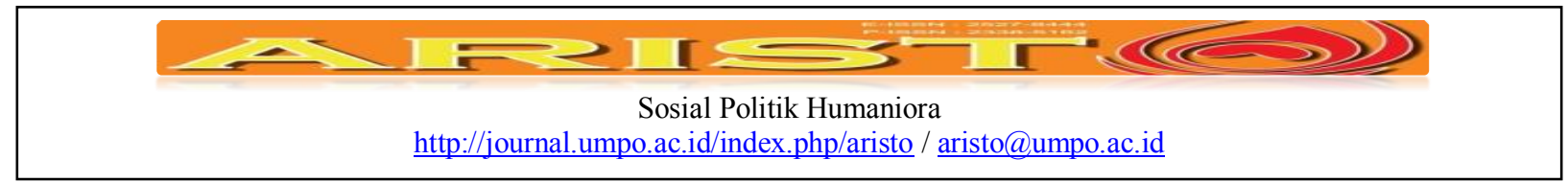

\section{DAFTAR PUSTAKA}

Angka, K. B. dalam. (2013). Kota Batu. BPS Profile Kota Batu, (Kota Batu dalam Angka), 1-11.

Atantia Riski Ananda. (2007). pembentukan KWK tahun 2007 tidak komunikatif kepada masyarakat Kungkuk secara utuh karena hanya melibatkan penggagas saja yaitu pihak perhotelan dan beberapa anggota masyarakat. Komunikasi di tingkat penggagas berjalan komunikatif-diskursif karenan ditunj. Skripsi Universitas Brawijaya Malang, 1(Pariwisata), 49.

Fadlina, I. M., Supriyono, B., \& Soeaidy, S. (2013). Perencanaan Pembangunan Pertanian Berkelanjutan (Kajian tentang Pengembangan Pertanian Organik di Kota Batu) Sustainable Development of Agrocultural ( Studies on Organic Agricultural Development in Batu City ). J. Pal UB, 4(1), 43-57.

Intyaswono, S. (2016). Peran Strategi City Branding Kota Batu Dalam Trend Peningkatan Kunjungan Wisatawan Mancanegara (Studi Pada Dinas Pariwisata dan Kebudayaan Kota Batu). Jurnal Administrasi Bisnis, 30 (1), 65-73.

Jupir, M. M. (2013). Implementasi Kebijakan Pariwisata Berbasis Kearifan Lokal. Journal Of Indonesian Tourism and Development Studies, 1(1), 28-37.

Miladiyah, U. R. (2014). Strategy Competitive Advantage untuk membangun City Branding Kota Batu Sebagai Kota Wisata. Skripsi Universitas Islam Negri Maulana Malik Ibrahim Malang, (Pariwisata), 2014.

Nurhidayati, S. E. (2009). Sistem Pariwisata di Agropolitan Batu Daftar Isi. Media Masyarakat, Kebudayaan Dan Politik, 22(1), 76 - 85.

Priambodo, M. P. (2015). Implementasi Kebijakan Ekonomi Pariwisata dan Perwujudan Pemberdayaan Masyarakat di Kota Batu. Jesp, 7(2), 27-34.

Putra, R. N. (2015). Implementasi Kebijakan Pengendalian Alih Fungsi Lahan Pertanian Di Kota Batu Sebagai Kawasan Agropolitan. Kebijakan Dan Manajemen Publik, 3(Kebijakan), 7180 .

Somantri, G. R. (2005). Gumilar Rusliwa Somantri. Jurnal Sosial Humaniora Makara UI, 9(2), $57-65$.

Suwandono, M. S. dan D. (2015). Perencanaan Desa Wisata Dengan Pendekatan Konsep Community Based Tourism ( CBT ) Di Desa Bedono ,. Jurnal Ruang UNDIP Semarang, $1(2), 61-70$.

Visi \& Misi Pemerintah Kota Batu diakses dari http://shining-batu.com/visi-misi-kota-wisata- 


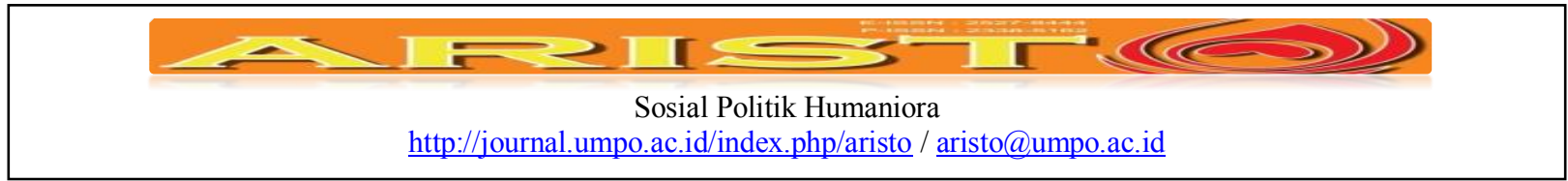

batu pada 20 Agustus 2016

Yeni Rosita. 2016. Aspek Hukum Perjanjian Kerjasama Usaha Pengelolaan Pariwisata Daerah Dihubungkan Dengan UU No. 10 Tahun 2009 Tentang Kepariwisataan www.http://repository.unpas.ac.id/.../1/Jurnal\%20Yeni\%20Rosita\%20MIHl.doc pada 20 Agustus 2016 